\title{
The Status and Seasonality in the Physico-chemical Hydrology of a Nigerian Rainforest Pond
}

\author{
Richard P. KING and Nathaniel A. NkAnTA
}

\begin{abstract}
Monthly and Seasonal regimes in the physico-chemical status of Mfangmfang pond, Uyo, Nigeria, were studied. Meteorological conditions depicted a short dry (November-February) and a prolonged wet (March-October) season. From the trends in hydrological variables, it was inferred that the integrated impact of precipitation, changes in pond level, input of surface runoff and municipal effluents played an overriding role in determining the absolute levels and temporal patterns in the water quality attributes. The physico-chemical parameters were assigned to three categories according to the types of seasonal and anthropogenic influences:

(1) Dry-season maximum (transparency, dissolved oxygen, free $\mathrm{CO}_{2}$, nitrate-nitrogen), resulting from low precipitation with concomitant reductions in input of surface runoff/municipal effluents and pond level.

(2) Wet-season maximum (suspended solids, conductivity, phosphate-phosphorus), resulting from increased precipitation with concomitant increases in the input of surface runoff/municipal effluents and pond level.

(3) No substantial seasonality (surface temperature, $\mathrm{pH}$, total alkalinity) due to absence of significant influences of the wet-dry season cycle and surface runoff/ municipal effluents.
\end{abstract}

Key words: tropical pond, seasonality, physico-chemical parameters, water quality

\section{Introduction}

Small freshwater ponds are common features of Nigerian inland waters. They support subsistence and artisanal fisheries, provide water for domestic purposes and are important spawning and nursery grounds for many fishes. Although a great deal has been documented on the water quality of Nigerian inland waters (Holden and Green, 1960; Egborge, 1971, 1979; Adebisi, 1981; Kinn et al., 1983; ChnDonem and EJIKE, 1985; Olusanya 1988), there is still a lacuna of information on the physico-chemical status of small ponds in the country. Studies on the water quality of ponds are important in evaluating the suitability of the water for aquatic biota, domestic, industrial and agricultural uses. This knowledge is important in the integrated development of good water quality/ fisheries management and conservation strategies.

This paper provides information on the status, monthly and seasonal regimes in some physico-chemical attributes of a rainforest pond (Mfangmfang pond) in Uyo, Akwa Ibom State, Nigeria, during the period, November 1986-October 1987 inclusive. It also examines the role of the dry-wet season cycle and anthropogenic influence (city runoff) on the seasonality regimes of the water quality parameters. The results are collated with those of other tropical lentic and fluviatile systems.

\section{Study area}

Mfangmfang pond (Fig. 1) was formed in 1980 by partially impounding the headwater of Iba-Oku stream by a weir during a gully erosion/landslide control exercise. It is located at 


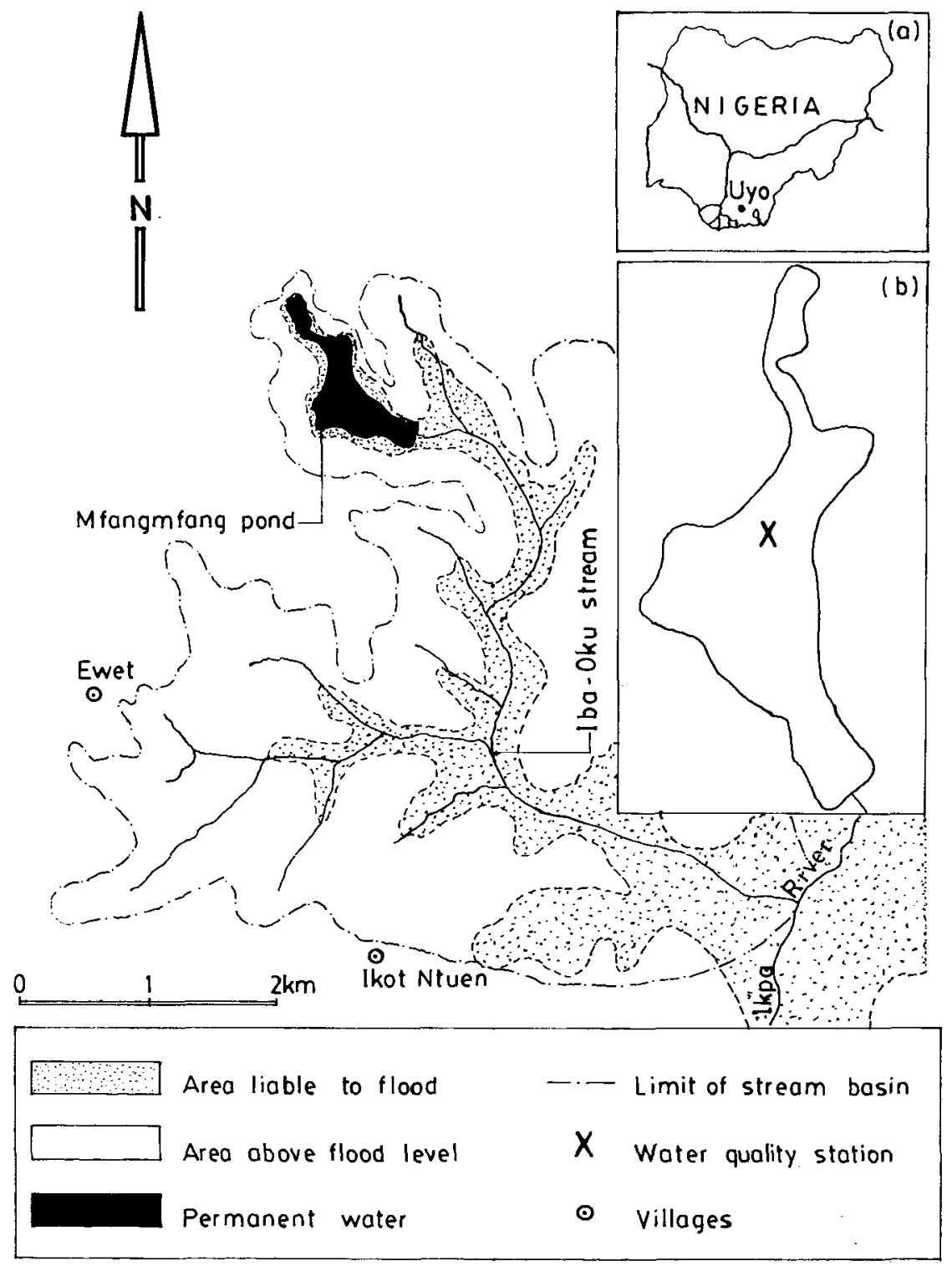

Fig. 1. Map of Iba-Oku stream basin, showing the location of Mfangmfang pond. Inset: (a) Map of Nigeria showing the location of Uyo; (b) Mfangmfang pond, showing the water quality station.

an altitude of less than $15 \mathrm{~m}$ above MSL and has an area of c. 29 ha; maximum length and width are c. 1500 and $575 \mathrm{~m}$, respectively; mean depth is $3.9 \mathrm{~m}$. The pond consists of a small northern basin and a larger southern basin. The bottom is predominantly $(79.2 \%)$ fine sand/mud while gravel and coarse sand form $20.7 \%$ and decaying macrophyte debris, $0.1 \%$ of the substratum (IKoTidem, 1987). About 90\% of the water surface of the southern basin is covered with floating leaves of Nymphaea while the northern basin is relatively more open. 
The littoral macrophytes comprise Nymphaea, Utricularia, Azolla, Echinochloa and Cyrtosper$m a$. The fringing swamps have semi-aquatic ferns and Cyrtosperma as dominant macrophytes; others include Raphia vinifera, R. hookeri, Elaeis guineensis, Pandanus candelabrum and Musanga sp.

The riparian zone is dominated by Hevea brasiliensis, Oxytenanthera abyssinica, $E$. guineensis and grasses. The soil of the catchment area is predominantly laterite. The pond is fed principally by ground seepage from aquifers and secondarily by precipitation, surface runoff and municipal effluents from Uyo metropolis. The unregulated outflow is through a ring culvert into Iba-Oku stream which subsequently discharges into Ikpa River at c. $7 \mathrm{~km}$ from the pond. The entire pondstream system drains a catchment area of $c$. $12.7 \mathrm{~km}^{2}$ and constitutes the main drainage system in Uyo metropolis $\left(5.01^{\circ} \mathrm{N}, 7.56^{\circ} \mathrm{E}\right)$.

\section{Materials and methods}

Monthly meteorological records were obtained from the University of Cross River State (Uyo, Nigeria) weather station (No. 0507. 05B) sited within Mfangmfang pond basin at an altitude of $65 \mathrm{~m}$ above MSL. A dry month was defined as one with an aridity index of less than 30 and a wet month as one with an aridity index equal to or greater than 30 . Aridity index was calculated according to the formula (EwER and $\mathrm{H}_{\text {ALLL, 1978): }}$

$$
\text { Aridity index }=\frac{12 P}{T+10}
$$

where $P$ is mean monthly rainfall $(\mathrm{m} m)$ and $T$, mean monthly air temperature $\left({ }^{\circ} \mathrm{C}\right)$. Temporal changes in pond water level were measured (cm) with a simple gauge.

Ten water physico-chemical parameters (surface temperature, transparency (TR), suspended solids ( $S S$ ), hydrogen ion concentration (pH), conductivity $(C D)$, total alkalinity, dissolved oxygen (DO), free carbon dioxide $\left(\mathrm{CO}_{2}\right)$, nitrate-nitrogen $\left(\mathrm{NO}_{3}-\mathrm{N}\right)$, phosphatephosphorus $\left.\left(\mathrm{PO}_{4}-\mathrm{P}\right)\right)$ were determined monthly based on records and samples taken from station X (Fig. 1).

All in situ determinations and collection of surface water samples were made during midmorning (10-11 a. m. local time). Water samples were collected with $125 \mathrm{ml}$ bottles for DO and large-mouthed 2-litre plastic vessels for other parameters. Water samples were analysed in the laboratory within $1 \mathrm{hr}$ of collection.

Surface temperature was measured in situ by a mercury-in-glass thermometer and $T R$, with a $25 \mathrm{~cm}$ (diameter) Secchi disc. The concentration of SS was estimated by filtering (under suction) 1 litre of water sample through a preweighed GF/C Whatman filter paper and ovendrying at $120^{\circ} \mathrm{C}$ for $12 \mathrm{hr}$; it was reweighed after cooling in a dessicator to obtain the amount of non-filtrable residue. The coefficient of coarseness $(C C)$ of suspended solids was estimated by dividing the concentration of $S S$ by TR (cf. Schlosser and Kark, 1981a). Hydrogen ion concentration $(\mathrm{pH})$ was measured with a battery powered PHJ-250-F Griffin meter and conductivity $(C D)$, with a Gensway digital meter. Other determinations were based on methods described in Al'1A (1976): dissolved oxygen was fixed in the field and the concentration estimated in the laboratory by Winkler method. Free $\mathrm{CO}_{2}$ was estimated in the field titrimetrically using $0.0027 \mathrm{~N} \mathrm{NaOH}$ and phenolphthalein indicator. Total alkalinity was estimated by titration with $0.02 \mathrm{~N} \mathrm{H}_{2} \mathrm{SO}_{4}$, using phenolphthalein and methyl orange indi. cators. $\mathrm{NO}_{3}-\mathrm{N}$ and $\mathrm{PO}_{4}-\mathrm{P}$ were determined colorimetrically using a Gallenkamp Color. imeter.

To evaluate the differences in physico-chemical attributes between the dry (November-February) and wet (March-October) seasons, the effect of monthly variation was smothered by averaging the levels of each parameter for each season. Intra-season variability in each water quality parameter was evaluated by coefficient of variation (standard deviation x 100/mean: Lowentine, 1966).

\section{Results}

The meteorological conditions in Mfangm- 
fang pond basin (Fig. 2) depicted a typical tropical seasonality regime with a short dry season and a prolonged wet-season. The dryseason was characterized by prevalence of hotdry northeasterly winds from the Sahara desert which resulted in low mean monthly rainfall
$(0.3-9.9 \mathrm{~cm})$ and high mean air temperature $\left(29.1-31.1^{\circ} \mathrm{C}\right)$; aridity index ranged from 0.9 to 28.9; peak dry-season occurred in DecemberJanuary. The dry-season was considered mild due to its brevity and the fact that there was always some precipitation in every month.
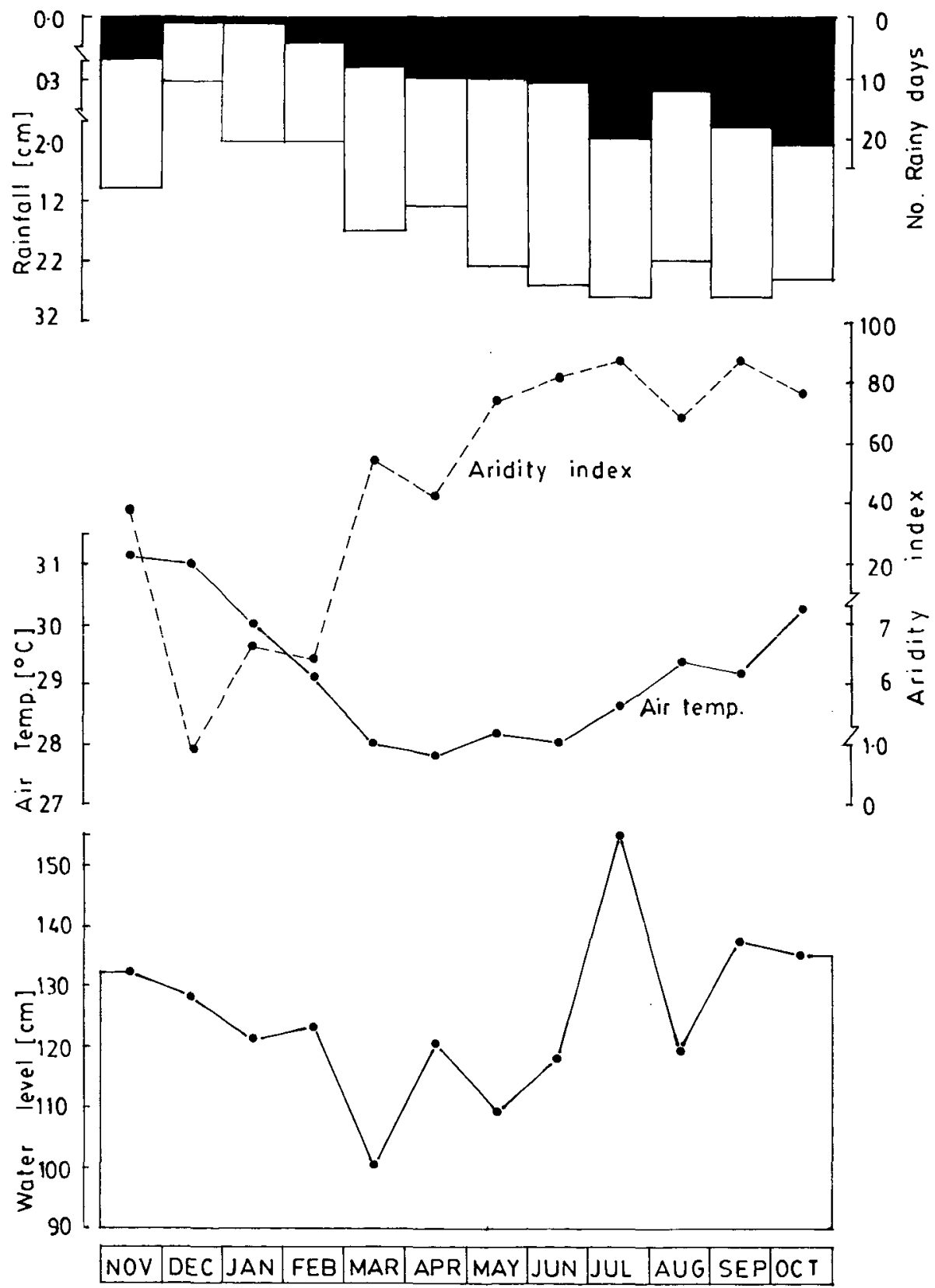

Fig. 2. Monthly variations in pond water level and meteorological conditions in the study area (November, 1986-October, 1987). 
The wet-season was characterized by prevalence of moist tropical maritime winds from the Atlantic Ocean and high mean rainfall (13.1$28.4 \mathrm{~cm}$ ) with a double maximum, in July and September; air temperature varied between 27.8 and $30.2^{\circ} \mathrm{C}$ and the aridity index was $41.6-86.9$. Annual rainfall was $197.3 \mathrm{~cm}$ (with 183 rainy days), $92.7 \%$ of which was received during the wet-season.

The water level (Fig. 2) started falling in November with the recession of the rains and reached its minimum in March. With the onset of heavy rains in May, it began to rise, reaching its first peak in July and the second in September, both of which coincided with the first and second rainfall maxima, respectively. There was an inverse relationship between rainfall and water level in November-April, probably due to the lag between the recession of the rains and the decrease in water level. However in May-October, when the soil of the riparian grounds must have been waterlogged, a positive relationship ensued. Annual range in water level was $37 \mathrm{~cm}$.

The surface temperature (Fig. 3a) was consistently lower than air temperature except in April and June when surface temperature was higher by 0.8 and $0.3^{\circ} \mathrm{C}$, respectively. Annual mean surface temperature was $27.4^{\circ} \mathrm{C}$; it ranged from $25.5^{\circ} \mathrm{C}$ in July to $29^{\circ} \mathrm{C}$ in November, these coinciding with the months of minimum and maximum air temperatures, respectively. There was no appreciable difference in mean surface temperature between the dry and wet seasons.

Transparency varied from $30 \mathrm{~cm}$ in June to $101.5 \mathrm{~cm}$ in January (Fig. 3b). The monthly changes showed high $T R(>80 \mathrm{~cm})$ in November-April and August-October and low TR (< $65 \mathrm{cni}$ ) in May-July. Mean $T R$ was higher in the dry than wet season.

Annual mean $S S$ was $216.8 \mu \mathrm{g} \cdot 1^{-1}$ and ranged from $10 \mu \mathrm{g} \cdot \mathrm{l}^{-1}$ in November, December and September to $200 \mu \mathrm{g} \cdot \mathrm{I}^{-1}$ in June (Fig. 3c). The monthly cycle in levels of SS showed a bimodal regime, with peaks in March and June. Mean concentration in the wet-season was appreciably higher than that of the dry-season.
Levels of $S S$ and reciprocal of $T R$ were positively related $(r=0.873, \quad d f=10, \quad P<0.002)$, with SS accounting for $76.2 \%$ of the variation $\left(r^{2}\right)$ in $T R$; linear regression equation for this relationship is:

$$
\frac{1}{T R}=0.011743+0.0000108 . S S
$$

The $C C$ of suspended solids (Fig. 3d) ranged from $0.1 \mathrm{in}$ December and September to 131.6 in June, the latter coinciding with the month of maximum $S S$ and minimum $T R$. Monthly variation in $C C$ depicted a bimodal pattern with peaks in March and June, a regime analogous to that of SS ( $c f$. Fig. 3c). Coefficient of coarseness of $S S$ was inversely correlated with $T R(r=-0.695, \quad d f=10, \quad P=0.02), \quad$ indicating that $T R$ decreased during periods of increasing levels of small particles of SS and vice-versa; about $48.3 \%$ of the variation in $T R$ was associated with coarseness of the SS. The linear regression equation for this relationship is:

$$
T R=103.03033-1.12771 C C .
$$

The wet-season mean $C C$ was higher by a factor 16.8 than the dry-season value; this indicates that large suspended solids constituted the bulk of the suspended load during the wetseason.

The pond, with an annual mean $\mathrm{pH}$ of 6.9 , may be considered neutral. $\mathrm{pH}$ was slightly less than 7 throughout the study period except in May, June and August, when values slightly exceeded neutrality (Fig. 3c). The monthly pH regime showed two main peaks, in May and August. pH ranged between 6.5 and 6.8 in the dry-season and 6.4-7.7 during the rains; there was no marked variation in mean $\mathrm{pH}$ for the two seasons.

Mfangmfang pond, with an annual mean $C D$ of $47.7 \mu \mathrm{S} \cdot \mathrm{cm}^{-1}$ was low in ionic content; $C D$ ranged from $40.7 \mu \mathrm{S} \cdot \mathrm{cm}^{-1}$ in January to 61.8 $\mu \mathrm{S} \cdot \mathrm{cm}^{-1}$ in June (Fig. 3f). Average wet-season $C D$ was higher than that of the dry-season by $7.2 \mu \mathrm{S} \cdot \mathrm{cm}^{-1}$. The $C D$ of Mfangmfang pond was significantly related to $S S(r=0.734, d f=$ $10, P<0.01$ ), with SS accounting for $53.9 \%$ of the variation in $C D$; linear regression equation 

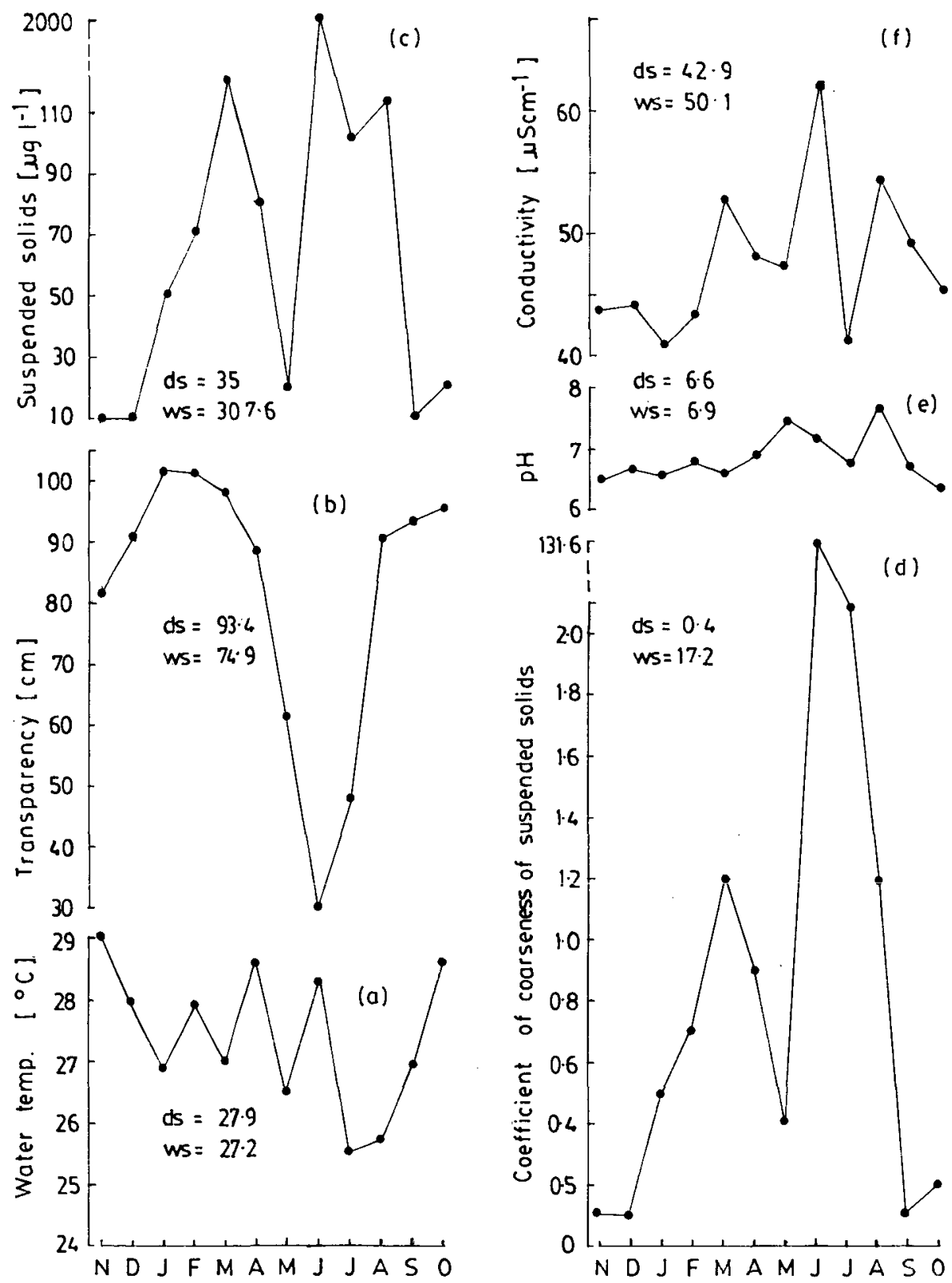

Fig. 3. Monthly and seasonal variations in surface temperature (a), transparency (b), suspended solids (c), coefficient of coarseness of suspended solids (d), $\mathrm{pH}(\mathrm{e}$ ), and conductivity (f) in Mfangmfang pond (November, 1986-October, 1987); ds=dry-season mean; ws= wet season mean.

for this relationship is:

$$
C D=45.98614+0.00806 S S .
$$

The reciprocals of $C D$ and $C C$ were negatively correlated $(r=-0.635, \quad d f=10, \quad P<0.05)$ according to the expression:

$$
\frac{1}{C D}=0.02183-0.00018 C C \text {. }
$$

About $40.3 \%$ of the variation in $C D$ was 
associated with the coarseness of suspended solids in the water.

The pond was moderately oxygenated, with an annual mean concentration and percentage saturation of $5.7 \mathrm{mg} \cdot \mathrm{l}^{-1}$ (range $2.6-8.3 \mathrm{mg} \cdot \mathrm{l}^{-1}$ ) and $72.1 \%$ (range $32.2-104.9 \%$ ), respectively. The DO did not attain 100\% saturation level throughout the year except in December when it was slightly supersaturated (Figs. 4a, b). The months of maximum and minimum DO (December and September, respectively) coincided with that of minimum and maximum levels of SS (Fig. 3c). Mean concentration of DO was higher by $1.6 \mathrm{mg} \cdot \mathrm{l}^{-1}$ (21\% saturation) during the dry than wet season; this was the converse of the seasonal regime in SS levels.

Phenolphthalein alkalinity was zero throughout the study period. It can therefore be inferred that $\mathrm{OH}^{-}$and $\mathrm{CO}_{3}{ }^{2-}$ ions made insignificant contributions to total alkalinity ( $c f$. Hat.. et al., 1977). This implies that total alkalinity was produced principally by $\mathrm{HCO}_{3}{ }^{-}$ion. Annual average total alkalinity was $9.9 \mathrm{mg} \cdot \mathrm{1}^{-1}$ $\mathrm{CaCO}_{3}$; it varied from $4 \mathrm{mg} \cdot \mathrm{I}^{-1}$ in May-June to $15 \mathrm{mg} \cdot \mathrm{l}^{-1}$ in July (Fig. 4c). Average total alkalinity was not markedly different in the dry and wet seasons.

Free dissolved $\mathrm{CO}_{2}$ was consistently higher than DO except in May when equal concentra. tions $\left(6 \mathrm{mg} \cdot \mathrm{l}^{-1}\right)$ were recorded. Annual mean free $\mathrm{CO}_{2}$ was $12.7 \mathrm{mg} \cdot \mathrm{l}^{-1}$ and ranged from 6 $\mathrm{mg} \cdot \mathrm{1}^{-1}$ in May to $24.4 \mathrm{mg} \cdot \mathrm{l}^{-1}$ in January (Fig. $4 d)$. Mean concentration of free $\mathrm{CO}_{2}$ was slightly higher in the dry than wet season.

The overall average concentration of $\mathrm{NO}_{3}-\mathrm{N}$ was $68 \mu \mathrm{g} \cdot 1^{-1}$. Levels were low $\left(<100 \mu \mathrm{g} \cdot 1^{-1}\right)$ in most months of the year, except FebruaryApril, when they were high $\left(>100 \mu \mathrm{g} \cdot \mathrm{I}^{-1}\right.$ ) (Fig. 4e). Maximum concentration $\left(400 \mu \mathrm{g} \cdot 1^{-1}\right)$ was attained in February while in May, it was below the limit of detection. Higher mean $\mathrm{NO}_{3}-\mathrm{N}$ occurred in the dry-season than during the rains.

Annual mean $\mathrm{PO}_{4}-\mathrm{P}\left(29.7 \mu \mathrm{g} \cdot 1^{-1}\right)$ was lower than that of $\mathrm{NO}_{3}-\mathrm{N}$ by $56.3 \%\left(38.3 \mu \mathrm{g} \cdot 1^{-1}\right)$. Monthly regime in $\mathrm{PO}_{4}-\mathrm{P}$ in Mfangmfang pond (Fig. 4f) showed three peaks (December, March and August respectively). Maximum concentration $\left(60 \mu \mathrm{g} \cdot \mathrm{I}^{-1}\right)$ occurred in August and minimum $\left(12.5 \mu \mathrm{g} \cdot \mathrm{I}^{-1}\right)$, in June. Mean $\mathrm{PO}_{4}-\mathrm{P}$ was slightly higher during the wet than dry season.

The intra-season variability in each physicochemical attribute of Mfangmfang pond (Table 1) indicates that $\mathrm{NO}_{3}-\mathrm{N}$ and $\mathrm{PO}_{4}-\mathrm{P}$ were more variable in the dry-season while all other parameters were more variable during the rains.

\section{Discussion}

The low surface temperature in Mfangmfang pond may be ascribed to the floating leaves of Nymphaea/overhanging macrophytes which preclude the effect of sun's insolation and the fact that temperature readings were taken during mid-morning. The absence of a marked seasonality in surface temperature in this pond is in consonance with the reports of ARMITAge. (1984) for tropical regulated streams and KRAMER (1978) for unregulated streams. However, it contradicts the regime in many tropical aquatic systems in which temperatures are higher in the dry- season than during the rains (Welcomme, 1979, 1985; Olusanya, 1988).

The patterns of seasonal variation in transparency and suspended solids in Mfangmfang pond are consistent with those in Opa reservoir, Nigeria (Olusanya, 1988) and rivers Zambezi (Hall et al., 1977) and Ogun, Nigeria (Adebisi, 1981). The decrease in transparency during the rains can be attributed to increased input of fine silt and particulate organic debris from the riparian zone through surface runoff while the high transparency during the dry- season may be due to sedimentation of suspended solids and decrease in the input of surface runoff $(c f$. Thomas and Ratci.sfe, 1973-Nunguna reservoir Ghana; ChiDoвem and EJIKE, 1985-Shen reservoir, Nigeria). The positive relationship between transparency and suspended solids indicates the role of the latter in determining the patterns of water clarity. The inverse relationship between the coefficient of coarseness of suspended solids and transparency is probably because large suspended particles scatter less light than an equal concentration of 

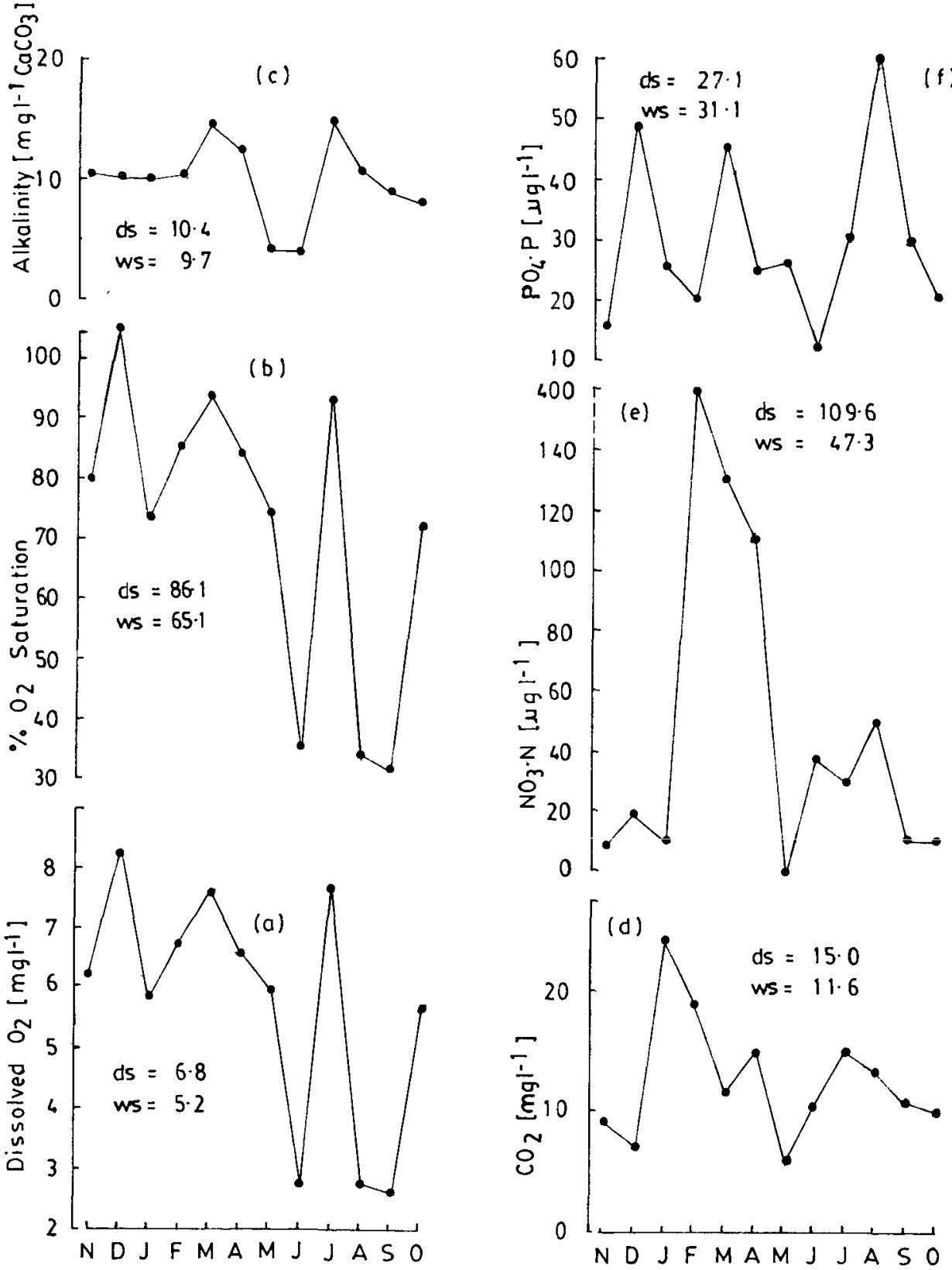

Fig. 4. Monthly and seasonal variations in dissolved oxygen (a), \% saturation of oxygen (b), total alkalinity (c), free carbon dioxide (d), nitrate-nitrogen $\left(\mathrm{NO}_{3}-\mathrm{N}\right)$ (e), and phosphate-phosphorus ( $\mathrm{PO}_{4}-\mathrm{P}$ ) (f) in Mfangmfang pond (November, 1986-October, 1987); ds=dry-season mean; ws = wet-season mean.

small particles (Grassy in Schlossser and Karr, 1981a).

The absence of a marked seasonality in the $\mathrm{pH}$ of Mfangmfang pond is probably due to the fact that most of the $\mathrm{H}^{+}$ions are not derived from external sources; thus the pond $\mathrm{pH}$ is unresponsive to increases in the input of precipitation, surface runoff and municipal effluents 
Table 1. Intra-season variability in the physico-chemical parameters of Mfangmfang pond.

\begin{tabular}{lrr} 
& Carameter & Coefficient of variation (\%) \\
\cline { 2 - 3 } & Dry-season & Wet-season \\
\hline Water level & 3.9 & 14.1 \\
Surface temperature & 3.1 & 4.6 \\
Transparency & 10.5 & 34.8 \\
Suspended solids & 85.7 & 222.8 \\
Coefficient of coarseness of suspended solids & 81.2 & 268.6 \\
Hydrogen ion concentration & 1.9 & 6.5 \\
Conductivity & 3.6 & 14.6 \\
Dissolved oxygen & 15.4 & 41.6 \\
Percentage saturation of oxygen & 15.8 & 41.4 \\
Total alkalinity & 3.2 & 44.1 \\
Free carbon dioxide & 16.0 & 26.2 \\
Nitrate-nitrogen & 176.7 & 102.0 \\
Phosphate-phosphorus & 54.4 & 48.1 \\
\hline
\end{tabular}

during the rains. It is also possible that the pond water is strongly buffered resulting in undetectable seasonal $\mathrm{pH}$ changes. The seasonality regime in the $\mathrm{pH}$ of Mfangmfang pond agress with the observations of Hall et al. (1977) in Zambezi river and Olusanyn (1988) in Opa reservoir but contradicts the trend in many African rivers in which $\mathrm{pH}$ is lower in the wetseason but rises during the dry-season (Egborge, 1971; Welcomme, 1975; Adebisi, 1981; Wright, 1982).

The low ionic content of Mfangmfang pond is comparable to that of Lake Kainji, Nigeria, with a conductivity of $46-99 \mu \mathrm{S} \cdot \mathrm{cm}^{-1}$ (Welcomme, 1986). The wet-season conductivity in Mfangmfang pond, which was higher than the dry-season value, is attributable to ionic enrichment of the pond through the input of municipal effluents and surface runoff from the riparian zone and/or 'solution effect' (Welcomme, 1979) whereby ions bound in previously semi-dry land by decaying macrophytes, dissolved as the water level increased and inundated fringing swamps and riparian zone. The seasonality regime in the conductivity of the pond contrasts with the pattern in tropical freshwater lagoons and rivers which are characterized by higher values in the dry-season (Welcomme, 1969, 1979, 1985; AdebisI, 1981; WriGHT, 1982). The positive relationship between conductivity and suspended solids in
Mfangmfang pond suggests that a large proportion of the ions in the pond exist in loosely adsorbed forms on the surfaces of suspended solids ( $c f$. ADEBISI, 1981). The inverse relationship between conductivity and coarseness of suspended solids indicates that small suspended particles are more effective in the transportation of ions than larger ones. The role of suspended solids as vehicles for the transport of ions in aquatic systems is discussed by DudLey and Karr (1978) and Scillosser (1978).

The inverse relationship between dissolved oxygen and suspended solids levels in the pond may be because a large proportion of the suspended solids comprised particulate organic matter whose decomposition resulted in depressed dissolved oxygen levels. Reduced dissolved oxygen levels may also be due to the flushing out of deoxygenated stagnant swamp water into the pond ( $c f$. Welcomme, 1975) and the decomposition of drowned macrophytes and other organic debris ( $c f$. HALL et al., 1977) during the high water period of the wet-season. Increased dissolved oxygen concentration in the pond during the dry-season was probably induced by photosynthetic activity of aquatic macrophytes (WeLcomme, 1975) and a decrease in the level of organic suspended solids. The seasonality regime in dissolved oxygen in Mfangmfang pond contrasts with the records of Carey (1971), Egborge (1971), Welcomme (1975) 
and Hall et al. (1977) that dissolved oxygen in tropical African aquatic systems is generally lower in the dry-season than during the rains.

The absence of a marked difference in mean total alkalinity between the dry and wet seasons in Mfangmfang pond sharply contrasts with the seasonality regimes in Opa reservoir (Olusanya, 1988) and some tropical rivers (Balon and Coche, 1974; Hall et al., 1977; Adebisl, 1981) which are characterized by higher alkalinity during the dry-season. The level of free carbon dioxide in Mfangmfang pond was slightly higher in the dry-season than during the rains. This disagrees with ADEBISI (1981) and Wright (1982), who recorded lower concentrations of free carbon dioxide during the dry-season in Ogun and Jong rivers, respectively.

The seasonal variation in nitrate-nitrogen concentration in Mfangmfang pond showed a higher value in the dry-season than during the rains. This can be ascribed to the slow enrichment of the pond through mineralization of organic matter discharged into the pond through surface runoff and municipal effluents during the wet-season. This seasonality regime is the converse of that in Lake Asejire, Nigeria (Eciborge, 1979) and Shen reservoir (CHidobem and EJIKE, 1985), where levels are higher in the wet-season. The seasonal pattern in levels of phosphate-phosphorus in the pond is consistent with the observations of Hall et al. (1977), Egborge (1979) and Olusanya (1988) for Zambezi river, Lake Asejire and Opa reservoir respectively.

The higher wet-season variability in most of the water quality parameters of the pond may be linked to the impacts of extrinsic factors ( $e$. $g$., rainfall, input of surface runoff and municipal effluents) which are more prominent during the rains than in the dry-season. Conversely, the higher dry-season variability in nitratenitrogen and phosphate-phosphorus indicates that the seasonal regimes in these attributes are influenced by subtle intrinsic factors which predominate during this season.

The physico-chemical hydrology of Mfangmfang pond revealed that the integrated impact of rainfall, accompanying fluctuations in pond level and discharge of municipal effluents and surface runoff from the riparian zone into the pond, tend to play an overriding role in determining the absolute levels and monthly/seasonal regimes in the water quality parameters. The physico-chemical attributes can be assigned to three categories according to the types of seasonal and anthropogenic influences:

(1) Dry-season maximum, resulting from low rainfall and concomitant reductions in pond level and input of surface runoff/ municipal effluents; transparency, dissolved oxygen, free carbon dioxide and nitrate-nitrogen are in this category.

(2) Wet-season maximum, resulting from increased rainfall, with concomitant increases in pond level and input of surface runoff/municipal effluents; suspended solids, conductivity and phosphatephosphorus is in this group.

(3) No substantial seasonal variation; parameters in this category (surface temperature, $\mathrm{pH}$ and total alkalinity) are not significantly influenced by the tropical wet-dry cycle or influx of surface runoff and municipal effluents.

\section{Acknowledgements}

The authors are indebted to Messrs Okon I. OKon and Ekpenyong A. Iкотшем, Department of Zoology and Fisheries, University of Cross River State, Uyo, Nigeria, for field and laboratory assistance.

\section{摘要 \\ あるナイジェリア多雨林池の 物理化学的水文状態と季節性}

ナイジェリア・Uyo の Mfangmfang 池の物理 化学的状態につき,その季節性を調べた。気象状 況は，短い乾季 (11月一 2 月) と長い雨季 (3月 -10月）に分けられた。水文的変動の傾向から， 降水・池水位・表流水の流入・都市排水などの総 合された影響が水質の絶対的水準と一時的な型を 決定していると解秎された。物理化学的パラメー 夕は，その季節性と人間活動の影響をもとに，以 下の 3 つに分類された。 
（1）乾季に最大となるもの（透明度・溶存酸素・ 遊離 $\mathrm{CO}_{2}$ ・硝酸性窒素)。これらは, 低い降水 量とそれに伴う表面流出・都市排水流入量の 隇少拉よび池水位の低下に起因する。

(2) 雨季に最大となるもの（SS・電導度・リン 酸性リン)。これらは, 高い降水量とそれに伴 う表面流出・都市排水流入量の増加および池 水位の上昇に起因する。

（3）季節性の無いもの（表面温度・ $\mathrm{pH} \cdot$ 全アル カリ度)。これらは, 雨季一乾季のサイクルお よび表面流出・都市排水の大きな影響を受け ないことによる。

\section{References}

Ademisi, A. A. (1981): The physico-chemical hydrology of a tropical seasonal river-upper Ogun river. Hydrobiologia, 79: 157-165.

APHA (1976): Standard methods for examination of water and waste water (14th ed). American Public Health Association.

Armitage, P. D. (1984): Environmental changes induced by stream regulation and their effect on lotic macro-inveterbrate communities, $p$. 139-165. In: A. Lillehammer and S. J. Saltveit (eds), Regulated rivers. Oslo Universitets-forlaget.

Balon, E. K. and A. G. COCHE (1974): Lake Kariba: A man-made tropical ecosystem in Central Africa. Monographiae Biologicae, 24, Junk, The Hague.

CAREY, T. G. (1971): Hydrological survey of the Kufue floodplain. Fish. Res. Bull. Zambia, 5: 245-295.

CHinobem, I. J. and C. EJIKE, (1985): An evaluation of the trophic status of the Shen reservoir by an analysis of phytoplankton composition and water characteristics. In: Proc. of the 4th Annual Conf. of the Fisheries Soc. of Nigeria (FISON), Port Harcourt, 26-29th Nov., 1985. 175-178.

DudLey, D. R. and J. R. KaRR (1978): Reconciling streambank erosion control with water quality goals. In: J. LAKE and J. MORRISON (eds), Environmental impact of land use on water quality: Final report on the Black Creek Project (Suppl. Comments), EPA-905/9-77-007-D. U. S. Environmental Protection Agency, Chicago, Illinois.

EGioRGE, A. B. M. (1971): The chemical hydrology of the River Oshun, Western State, Nigeria. Freshwat. Biol., 4: 177-191.

EGiborge, A. B. M. (1979): The effect of impound- ment on the water chemistry of Lake Asejire, Nigeria. Freshwat. Biol., 9: 403-412.

Ewer, D. W. and J. B. Hal. (ed.) (1978): Ecological Biology 2: The inter-relations of organisms. Longman Group Ltd.

Hall, A., I. M. C. B. S. Valente, and B. Davies (1977): The Zambezi River in Moçambique: The physico-chemical status of the middle and lower Zambezi prior to the closure of the Cabora Bassa Dam. Freshwat. Biol., 7: 187206.

Holden, M. J. and J. Green (1960): The hydrology and Plankton of the River Sokoto. J. Anim. Ecol., 29: 65-84.

IKoTidem, E. A. (1987): The zonal distribution of fishes along Iba-Oku stream, Uyo, Cross River State, Nigeria. Thesis, University of Cross River State, Uyo, Nigeria. $54 \mathrm{p}$.

KARR, J. R. and I. J. Schlosser (1987): Water resources and land-water interface. Science, 201: 209-234.

Kilan, M. A., T. Fagbemi, and C. Ejike (1983): Diurnal variations of physico-chemical factors and planktonic organisms in Jos Plateau (West Africa) water reservoir. Jpn. J. Limnol., 44 (1): 65- 71.

KRAMER, D. L. (1978): Reproductive seasonality in the fishes of a tropical stream. Ecology, 59: 976- 985.

LowENTINE, R. C. (1966): On the measurement of relative variability. Systematic Zool., 15: 141142.

Olusanya, A. O. (1988): The studies of the physicochemical factors and diatom flora of Opa reservoir, Obafemi Awolowo University (Univ. of Ife), Ile-Ife, Nigeria. Thesis, Obafemi Awolowo University, Ile-Ife, Nigeria. $183 \mathrm{p}$.

Schlossie, 1. J. and J. R. KARR, (198la): Riparian vegetation and channel morphology impact on spatial patterns of water quality in agricultural watersheds. Environ. Manag., 5 (3): 233-243.

Schlosser, I. J. and J. R. Karr (1981b): Water quality in agricultural watersheds: Impact of riparian vegetation during base flow. Wat. Res. Bull., 17 (2): 233-240.

Triomas, J. D. and P. J. Ratclifre (1973): Observations of the limnology and primary production of a small man-made lake in the West African Savanna. Freshwat. Biol., 3: 573-612.

Welcomme, R. L. (1975): The biology and ecology of the fishes of a small tropical stream. J. Zool, Lond, 158: 485-529.

Welcommk, R. L. (1975): The fisheries ecology of 
African floodplains. FAO/CIFA Tech. Pap. 3. $51 \mathrm{p}$.

Welcomme, R. L. (1979): Fisheries ecology of floodplain rivers. Longman Group Ltd. Lond.

Welcomme, R. L. (1985): River fisheries. FAO Fish Tech. Pap., 262.

Welcomme, R. L. (1986): The Niger River system, p. 9-23. In: B. R. DAvies and K. F. WALKER (eds), The ecology of river systems. W. Junk Pub., Dordrecht.

WRIGHT, R. (1982): Seasonal variations in water quality of a West African river (R. Jong in Sierra Leone). Rev. Hydrobiol. trop., 15 (3): 193- 199.

(Richard P. KING and Nathaniel A. NKanta, Dept. of Zoology and Fisheries, University of Cross River State, P. M. B. 1017, Uyo, Nigeria).

Received: 18 September 1989

Accepted: 31 August 1990 